\title{
Artificial inoculation on plants and banana leaf pieces with Mycosphaerella spp., responsible for Sigatoka leaf spot diseases
}

Catherine AbAdIE ${ }^{2 \star}$, Marie-Françoise ZAPATER $^{1}$, Luc PIGNOLet ${ }^{1}$, Jean CARLIER $^{1}$, Xavier Mourichon ${ }^{1}$

${ }^{1}$ CIRAD, UMR BGPI, TA A 54/ K, 34398, Montpellier Cedex 5 , France

2 CIRAD, UPR Mult. Vég., Stn. Neufchâteau, 97130,

Capesterre Belle-Eau, Guadeloupe, France

catherine.abadie@cirad.fr
${ }^{*}$ Correspondence and reprints

Fruits, 2008, vol. 63, p. 319-323 (C) 2008 Cirad/EDP Sciences All rights reserved DOI: $10.1051 /$ fruits:2008030 www.fruits-journal.org

Artificial inoculation on plants and banana leaf pieces with Mycosphaerella spp., responsible for Sigatoka leaf spot diseases.

Abstract - Introduction. This protocol aims at (i) analysing the nature of host-parasite interactions (resistance or susceptibility), and (ii) studying the variability of the pathogenicity of different pathogen populations (intra/inter-specific) with regard to both virulence and aggressiveness using artificial inoculation with Mycosphaerella fijiensis or Mycosphaerella musicola on plants and banana leaf pieces. The principle, key advantages, starting plant material and time required for the method are presented. Materials and methods. Laboratory materials required and details of the sixteen steps of the protocol (conidial inoculum preparation, artificial inoculation on banana plants and artificial inoculation on banana leaf pieces) are described. Possible troubleshooting is discussed. Results. Typical symptoms of the different diseases are obtained after artificial inoculation.

France / Musa sp. / Mycosphaerella fijiensis / Mycosphaerella musicola / disease resistance / methods

Inoculation artificielle sur plants et tissus de feuille de bananier avec Mycosphaerella spp., responsables de la maladie de Sigatoka.

Résumé - Introduction. Ce protocole vise (i) à analyser la nature des interactions hôtesparasites (résistance ou sensibilité), (ii) à étudier la variabilité de la pathogénicité de différentes populations pathogènes (intra/interspécifiques) quant à leur virulence et leur agressivité mesurées à partir d'inoculation artificielle avec Mycosphaerella fijiensis ou Mycosphaerella musicola sur des plants et des morceaux de feuille de bananier. Le principe, les principaux avantages, le matériel végétal de départ et le temps nécessaire de la méthode sont présentés. Matériel et méthodes. Le matériel de laboratoire nécessaire et le détail des seize étapes de réalisation du protocole (préparation de l'inoculum conidial, inoculation artificielle sur des plants de bananier, et inoculation artificielle sur des morceaux de feuille de bananier) sont décrits. Des problèmes potentiels sont évoqués. Résultats. Des symptômes-types de la maladie sont obtenus après inoculation artificielle.

France / Musa sp. / Mycosphaerella fijiensis / Mycosphaerella musicola / résistance aux maladies / méthode

\section{Introduction}

\section{Applications}

This protocol aims at (i) analysing the nature of host-parasite interactions (resistance or susceptibility), and (ii) studying the variability of the pathogenicity of different pathogen populations (intra/interspecific) with regard to both virulence and aggressiveness using artificial inoculation with Mycosphaerella fijiensis or M. musicola on plants and banana leaf pieces. 


\section{Principle}

During the last few decades, the evaluation of banana resistance against Mycosphaerella leaf spot diseases has only been performed in the field under natural and, hence, variable conditions; for example, parasite pressure and, above all, under climatic conditions that differed very considerably from one location to another. The importance of environmental factors for the expression of resistance, and especially partial resistance, is well known [1]. This constraint can be overcome using artificial inoculations with Mycosphaerella isolates under controlled conditions. The principle of artificial inoculation methods is to apply the same inoculum quantity on bananas cultivated under the same conditions.

Two kinds of artificial inoculation method are presented in this protocol: (i) the inoculation of young plants derived from tissue culture cultivated under controlled environmental conditions in climatic chambers [2] and (ii) a miniaturised technique based on the use of leaf fragments from mature plants as starting materials and maintained on a culture medium.

The first method requires the use of juvenile plants as host plants which can sometimes result in resistance phenotypes that are not true-to-type (due to differences in the leaf physiology between vitroplantlets and adult plants). The second method requires more time because of the cultivation of plants in a greenhouse for several months before taking fragments of young leaves.

\section{Key advantages}

- Artificial inoculation methods allow to decrease the effect of the environment in the host-parasite interactions and to produce accurate and reproducible data.

- The artificial inoculation method on banana plants allows the observation of disease development stages in relation to the development of the plant.

- In the artificial inoculation on banana leaf pieces, all the stages of development of monocyclic infection are reproduced. It takes into account the physiology of banana leaves. The miniaturisation allows the comparison of many banana accessions or strains in the same experiment.

\section{Starting material}

- For the inoculation technique on banana plants, the method requires banana plants derived from in vitro multiplication, inoculated 10 weeks after the beginning of acclimatisation (plant size 40-60 cm, 10 leaves) as described by Mourichon et al. [2].

- For the inoculation technique on leaf pieces, banana plants are initiated from tissue culture plants, and acclimated in pots $(0.25 \mathrm{~L}$, then $1 \mathrm{~L}$ ) containing compost (Neuhauss $\mathrm{n}^{\circ} 9$ containing $80 \%$ of peat) for 3 months at $80 \%$ humidity, (26 to 28 ) ${ }^{\circ} \mathrm{C}$ and a 12-h light period. The plants are transplanted into 5-L pots containing a mixture of compost and pozzolan [3 vol.:1 vol.] and cultivated in a greenhouse at $70-80 \%$ humidity, (26 to 28 ) ${ }^{\circ} \mathrm{C}$ for (2 to 4) months. Powder fertiliser (Osmocote N10-P11-K18) is added to the mixture ( $3 \mathrm{~g}$ of Osmocote per $5 \mathrm{~L}$ of substrate). Then liquid fertiliser (Mairol or Hortal at $1 \mathrm{~g} \cdot \mathrm{L}^{-1}$ ) is amended every 2 weeks during this cultivation. Banana plants have to be grown under optimum physiological conditions before sampling. Some insecticides can be applied if necessary.

\section{Time required}

For plant inoculation, the total time from the artificial inoculation and the observation of symptoms is from (2 to 5 ) weeks and, for inoculated leaf fragments, from (3 to 12) weeks are needed according to the desired infectious stages of the disease.

\section{Materials and methods}

\subsection{Laboratory materials}

The protocol requires some classical equipment for microbiological studies and some specific equipment such as: 
- climatic chambers (one with humidity for the acclimatisation of vitroplants, one with circular air),

- a greenhouse,

- haematological count cells,

- a microsprayer (about $1.5 \mathrm{~kg} \cdot \mathrm{cm}^{-2}$, artist's airbrush type),

- a microscope for routine laboratory applications, and an optic microscope.

\subsection{Protocols for artificial inoculation}

\section{Conidial inoculum preparation}

- Step 1

Fungal cultures should be monosporic and stored in glycerol $(15 \%)$ at $-80^{\circ} \mathrm{C}$.

- Step 2

Inoculate V8 300-medium plates $(300 \mathrm{~mL}$ of vegetable juice $\mathrm{V} 8,3 \mathrm{~g}$ of $\mathrm{CaCO}_{3}, 20 \mathrm{~g}$ of agar, $700 \mathrm{~mL}$ of water amended with $100 \mathrm{UI} \cdot \mathrm{mL}^{-1}$ of penicillin and $100 \mu \mathrm{g} \cdot \mathrm{mL}^{-1}$ of streptomycin sulphate after sterilisation) with 4-5 small plugs from a 10-d-old PDA mycelium culture (39 $\mathrm{g}$ of potato dextrose agar, $1000 \mathrm{~mL}$ of water amended with $100 \mathrm{UI} \cdot \mathrm{mL}^{-1}$ of penicillin and $100 \mu \mathrm{g} \cdot \mathrm{mL}^{-1}$ of streptomycin sulphate after sterilisation).

- Step 3

Incubate these plates for about $10 \mathrm{~d}$ at $25^{\circ} \mathrm{C}$ with a 12-h light period.

- Step 4

Place four to five V8-300 mycelium plugs in $20 \mathrm{~mL}$ sterile water, roughly crushed and split with an ultrasound ( $3 \mathrm{~mm}$ in diameter) for $1 \mathrm{~min}$ at $80 \mathrm{~W}$ power.

\section{- Step 5}

Pour about $2 \mathrm{~mL}$ of the solution on V8sporulation medium $(100 \mathrm{~mL}$ of vegetable juice V8, $0.2 \mathrm{~g}$ of $\mathrm{CaCO}_{3}, 20 \mathrm{~g}$ of agar, $900 \mathrm{~mL}$ of water with the same antibiotics as described in step 2, and $\mathrm{pH}$ adjusted to 6).

\section{- Step 6}

Incubate the inoculated V8-sporulation plates at $20^{\circ} \mathrm{C}$ under continuous light for 2 weeks.
- Step 7

Add a few mL of sterile water to sporulation plates and lightly brush the colony surface with a plastic spatula. The conidial solution can be filtered if too many mycelium fragments are present in the suspension.

- Step 8

Check the conidial concentration with a haematological count cell (Malassez) and adjust the conidial suspension to the expected concentration (usually $10^{4}$ spores $\cdot \mathrm{mL}^{-1}$ to inoculate plants and $3.10^{3}$ spores $\cdot \mathrm{mL}^{-1}$ to inoculate leaf fragments).

\section{Artificial inoculation on banana plants}

- Step 9

Spray approximately $1 \mathrm{~mL}$ of suspension on the lower surface of the youngest leaves using a microsprayer at constant pressure $\left(1.5 \mathrm{~kg} \cdot \mathrm{cm}^{-2}\right)$.

\section{- Step 10}

Place inoculated plants in a climatic chamber with relative humidity allowing a saturated atmosphere, at $25^{\circ} \mathrm{C}$, and under a $12 \mathrm{~h} / 12 \mathrm{~h}$ photoperiod.

\section{- Step 11}

After 1 week, reduce the relative humidity to $80 \%$.

Note: first symptoms appear after 10-15 d of incubation, and the time from the first to final necrosis lesions differs according to the level of host susceptibility: from 20-25 d for a susceptible plant to 60-70 d for a highly partially resistant cultivar (figure 1).

\section{Artificial inoculation on banana leaf pieces}

- Step 12

Select the youngest fully mature leaf from plants (if necessary the second youngest leaf may be used as well), cut it and bring it back to the laboratory. To conserve the leaf until needed, put the stem in water.

- Step 13

Cut leaf pieces (with a $6 \mathrm{~cm} \times 6 \mathrm{~cm}$ plastic square) and place them in a petri dish with the upper leaf surface face down on the survival medium $(0.4 \%$ water:agar and $50 \mathrm{mg}$ benzimidazole (Sigma product, ref. 


\section{Abadie et al.}

Figure 1.

Symptoms of Black Leaf Streak disease, $35 \mathrm{~d}$ after an artificial inoculation of banana plants with Mycosphaerella fijiensis.

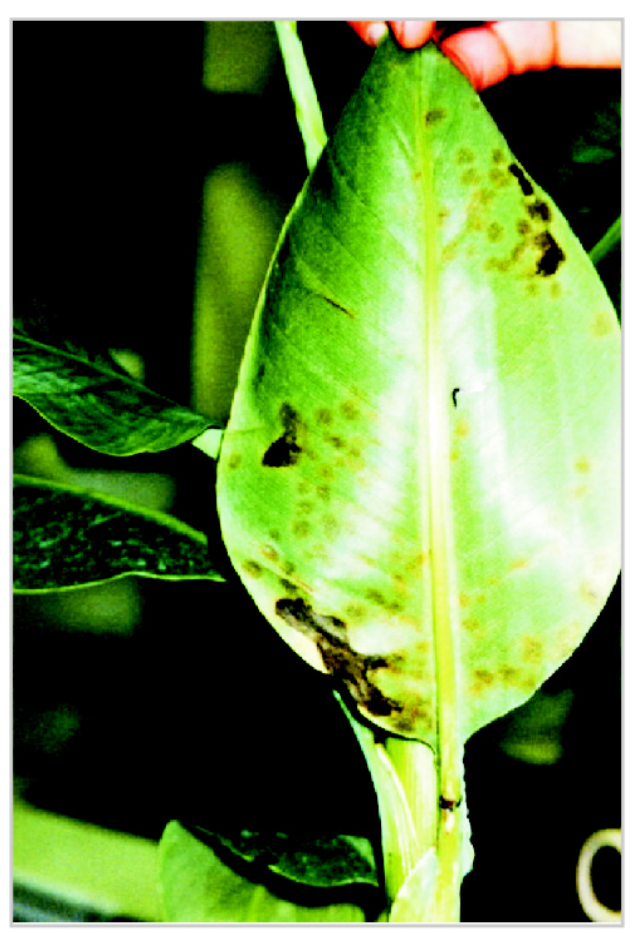

Note: first symptoms appear after 18-20 d of incubation, and the time from the first to final necrosis lesions differs according to the level of host susceptibility from $30 \mathrm{~d}$ for susceptible plants to $60-70 \mathrm{~d}$ for a partially resistant cultivar.

\subsection{Troubleshooting}

Two key problems can occur in these two artificial inoculation methods:

(a) The lesion development is not homogeneous on banana plants. Solution: check the climatic conditions of the chamber.

(b) A high mortality of leaf fragments is observed. Solution: check the good physiological state of mature banana plants in the greenhouse (optimised fertilisation, no insect sting) and the good air circulation in the plate incubation chamber (no condensation should occur on the lids).

\section{Typical results obtained}

Typical symptoms of Mycosphaerella leaf spot diseases are observed after inoculation of banana plants (figure 1) or banana leaf fragments (figure 2). The observations will depend on the objectives of each study (host screening for susceptibility/resistance or fungi aggressiveness). Lesions can be counted (number of lesions) or measured (surface). They can be done in kinetics or at only one date as described in [3].

\section{- Step 15}

Perform inoculations by spraying the leaf pieces with $1 \mathrm{~mL}$ of conidial suspension, with a microsprayer $\left(1.5 \mathrm{~kg} \cdot \mathrm{cm}^{-2}\right)$, held vertically over the leaf pieces at a height of $40 \mathrm{~cm}$ or, alternatively, placing $2 \mu \mathrm{L}$ or $4 \mu \mathrm{L}$ droplets of conidial suspension on the leaf.

- Step 16

Incubate leaf pieces at $25{ }^{\circ} \mathrm{C}$ with a $12 \mathrm{~h} /$ $12 \mathrm{~h}$ photoperiod (4000 lux approximately) for symptom expression.

Caution: it is very important to avoid any condensation in the petri dish to keep leaf pieces alive (figure 2). Use a climatic chamber with a circular movement of fresh air.

\section{References}

[1] Fouré É, Mourichon X., Jones D.R., Black leaf streak disease. Evaluating germplasm for reaction to black leaf streak, in: Jones D.R. (Ed.), Diseases of banana, abaca and enset, CABI Publ., Wallingford, UK, 2000, pp. 62-67.

[2] Mourichon X., Peter D., Zapater M.F., Inoculation expérimentale de Mycosphaerella fijiensis Morelet sur jeunes plantules de bananiers issues de cultures in vitro, Fruits 42 (4) (1987) 195-198. 
[3] Abadie C., Pignolet L., Elhadrami A., Habas R., Zapater M.F., Carlier C., Inoculation avec Mycosphaerella sp., agent de cercosporioses, de fragments de feuilles de bananiers maintenus en survie, Cah. Tech. INRA Numéro spéc. Méthodes d'appréciation du comportement variétal vis-à-vis des bioagresseurs, INRA, Paris, France, 2005, pp. 131-134.

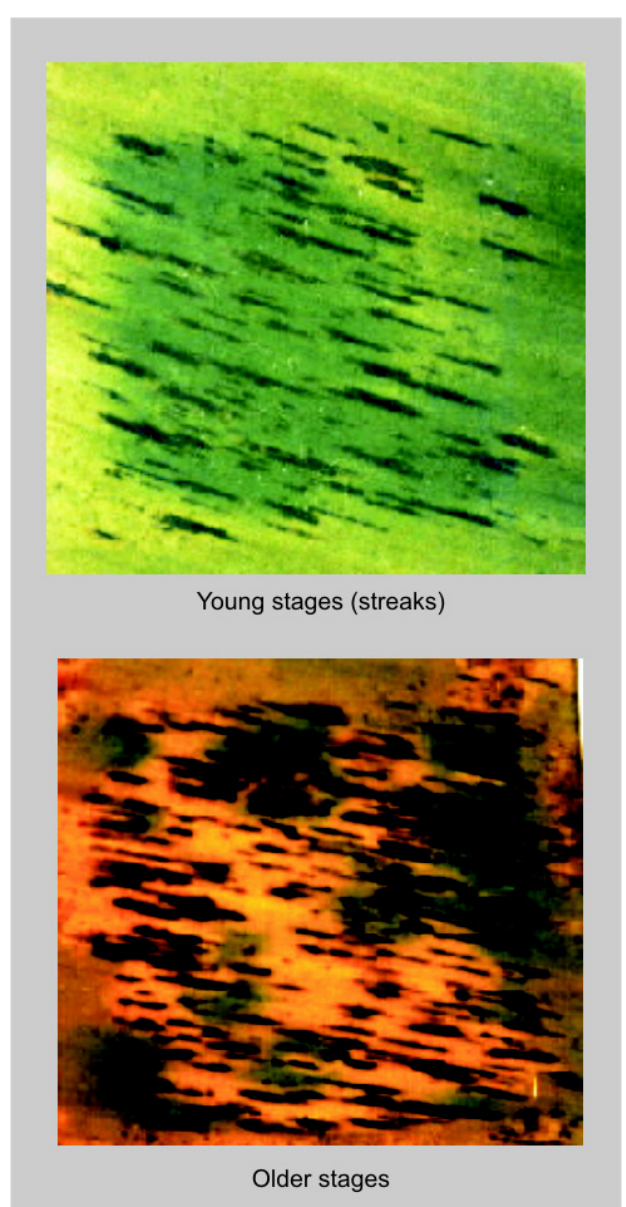

Figure 2.

Symptoms of Black Leaf Streak Disease after an artificial inoculation of banana leaf pieces with Mycosphaerella fijiensis. 